\title{
The Academic Resilience of College Students in Kalinga
}

\author{
Sheila Mae Carol A. Buslig \\ Kalinga State University \\ Tabuk City, Kalinga, Philippines 3800
}

\begin{abstract}
This study investigated the poverty experiences and academic resilience of college students in Kalinga and its relationship to their academic performance. The study was conducted at the Kalinga-Apayao State College being the only state college in the province. The respondents were one hundred (100) college students who generally come from indigent families. The sample for the study was determined through stratified random sampling. The students were requested to answer the questionnaires and were interviewed at their most convenient time narrating their struggles and challenges about their studies and poverty experiences. Specifically, the study determined the socio-economic and academic profile of the respondents. It also ascertained the socio-economic condition of the respondents, their level of academic resilience and academic performance. Finally, the study also tested the hypotheses: There is no significant relationship between the respondents' academic resiliency and academic performance. On the whole, the indicators of socio-economic conditions of the respondents reveal that most of them come from poor families and they live a simple life. The study further reveals that the over-all weighted mean of academic resilience of the respondents is 3.64 which has a descriptive value of "much resilient". Finally, the study accepted the null hypothesis that there is no significant relationship between the respondents' academic resiliency and academic performance. This implies that academic resiliency does not in no way influence academic performance. Moreover, the students of Kalinga are academically resilient since they are able to successfully adjust and cope with stressful circumstances in their lives despite diversity. It is an indication that these respondents are optimistic, as they adopt a proactive and positive orientation to their studies.
\end{abstract}

Keywords: Academic resilience, Academic performance, College students

\section{Introduction}

This study will provide knowledge and information that will promote academic resilience to students. It is to see how students battle with academic problems and difficulties. It is a way for them to be successful and remove inferiority in themselves with regards to academic capabilities. The purpose of this study is to assess the potential individual characteristics and environmental factors that promote academic resilience among college students of low socioeconomic status (SES) in Cordillera and the province of Kalinga as well. It assessed the level of academic resilience of college students and how academic resilience promoted academic performance. In other words, an array of factors was examined to see which factors promoted or hindered academic resilience functioning across the academic competence domain among students in poverty.

\section{Methodology}

The researcher used the descriptive-correlation method. The descriptive survey method of research is directed toward ascertaining the conditions that prevail in a group of cases chosen for study. Such method is used considering that the study seeks to investigate the profile of the college students in Kalinga, their personal and socio-economic profile, academic profile, their academic performance and their academic resilience. Moreover, it explored the significant difference between their academic performance and academic resilience to their profile variables and determined if there is a significant relationship between their academic performance and academic resiliency.

\section{Respondents of the Study}

The respondents were one hundred (100) college students who generally come from indigent families. The sample for the study was determined through stratified random sampling. The students were requested to answer the questionnaires and were interviewed at their most convenient time narrating their struggles and challenges about their studies and poverty experiences.

\section{Instrumentation}

The major tool for gathering data was the questionnaire. This questionnaire was used as a survey on the academic resilience of college students. This survey has three parts. 
The first part is concerned with the students' profile in terms of personal, socio-economic, and academic profile. The second part is concerned with the socio-economic condition of the respondents. The third part is concerned with the level of academic resilience of the respondents. This is to find out how resilient college students in their academic endeavors. The students will be asked to rate on a 5-point scale how the statements apply to them and promote their educational success. This is to find out how resilient college students in their academic endeavors. This part will determine the level of academic resilience of the respondents.

Moreover, an interview guide with students and teachers will be done to supplement and validate the information provided by the respondents. This interview guide will look deeper into the lived experiences of the respondents.

\section{Data Analysis}

To attain an objective interpretation and analysis of data the following statistical tools were used: the frequency and percentage distribution, the weighted mean, slovin formula, analysis of Variants (ANOVA), T-test, and the Pearson Product Moment Correlation. The frequency and percentage distribution quantified the overall responses on the profiles of the respondents. The weighted mean quantified the overall responses of the students on their level of resilience. The Slovin formula was used to determine the sample for the study. The Analysis of Variants (ANOVA) tested the significant differences on the level of academic resilience of the students and the significant difference on the level academic performance of the students and the Pearson Product Moment Correlation measured the relationship between the academic performance and academic resiliency of the respondents.

\section{Literature review}

Children living in poverty are more exposed to family turmoil, less stimulating home environments and lower quality schools than non-poor children (Evans, 2004). Yet, not all students from low-income families are at risk for academic failure as poor children vary on a variety of other factors linked to academic outcomes. Poverty increases the odds of such failure but more proximal risks play an important role as well.

Higher education helps reduce poverty. According to Barbara J. Astle, 2005, Higher education is one of the most powerful yet underestimated means that countries can rely on to reduce poverty and achieve social and economic development goals. Most people recognize its value for productivity and growth in developed countries, but some people inexplicably consider university education a luxury for developing countries. It is not a luxury, it is essential.

Similarly, they say, science, technology and innovation must be front and centre in achieving the millennium development goals. Imagine trying to achieve one of these goals - universal primary education - without higher education. This would mean providing primary education without training teachers, without developing locally relevant curriculum, and without equipping the principals and ministry of education officials with solid management and governance skills. These kinds of specialized training take place within universities, and point to the importance of achieving a narrow view of basic education delivery in favor of a more sustainable approach to education - an approach that capitalizes on the complementary roles of primary, secondary and tertiary education. Higher education provides fundamental expertise to all sectors of society and the economy, including the key sectors that drive development - health, education, governance, private sector development and the environment.

In the Philippines, local universities help developing countries to train their own business leaders, policy-makers, scientists, teachers and front-line service professionals instead of relying on foreigners. University graduates have the specialized skills to earn a living and infuse their sector of employment - whether in the private industry, the public sector or civil society - with the expertise that underpins success.

\section{Results and discussion}

\section{1 Socio-economic Profile of Respondents}

The socio-economic profile is a vital data to determine the standard of living of the respondents. This data is essential as it provides a glimpse on the kind of life the respondents live in their respective families. 
Table 1. Socio-economic Profile of Respondents

\begin{tabular}{|c|c|c|}
\hline Socio-economic Profile & $\begin{array}{l}\text { Frequency } \\
(\mathrm{N}=100)\end{array}$ & Percentage \\
\hline \multicolumn{3}{|l|}{ Parent's occupation } \\
\hline $\begin{array}{l}\text { Farming } \\
\text { Piggery/poultry } \\
\text { Teaching } \\
\text { Construction worker } \\
\text { Vending } \\
\text { Government worker } \\
\text { Others }\end{array}$ & $\begin{array}{r}60 \\
18 \\
6 \\
2 \\
1 \\
5 \\
8\end{array}$ & $\begin{array}{l}60 \\
17.6 \\
5.80 \\
2.40 \\
1.20 \\
5.40 \\
7.60\end{array}$ \\
\hline \multicolumn{3}{|l|}{ Family’s Main Income } \\
\hline $\begin{array}{l}\text { Piggery/Poultry } \\
\text { Gardening/Vegetable } \\
\text { Carpentry } \\
\text { Government employment } \\
\text { Private employment } \\
\text { Rice and corn } \\
\text { Others }\end{array}$ & $\begin{array}{r}7 \\
29 \\
8 \\
10 \\
5 \\
23 \\
18\end{array}$ & $\begin{array}{r}7.20 \\
28.8 \\
7.80 \\
10.20 \\
4.80 \\
23.40 \\
17.80\end{array}$ \\
\hline \multicolumn{3}{|l|}{ Family structure } \\
\hline $\begin{array}{l}\text { Two parent household } \\
\text { Single parent household }\end{array}$ & $\begin{array}{l}78 \\
22\end{array}$ & $\begin{array}{l}78 \\
22\end{array}$ \\
\hline Socio-economic Profile & $\begin{array}{l}\text { Frequency } \\
(\mathrm{N}=100)\end{array}$ & Percentage \\
\hline \multicolumn{3}{|l|}{ Religion } \\
\hline $\begin{array}{l}\text { Roman Catholic } \\
\text { Non-Roman Catholic }\end{array}$ & $\begin{array}{l}68 \\
32\end{array}$ & $\begin{array}{l}68.40 \\
31.60\end{array}$ \\
\hline $\begin{array}{c}\text { Parent's Highest Educational Attair } \\
\text { Elementary undergraduate } \\
\text { Elementary graduate } \\
\text { High school level } \\
\text { High school graduate } \\
\text { College undergraduate } \\
\text { College graduate } \\
\text { Vocational graduate }\end{array}$ & $\begin{array}{r}17 \\
11 \\
18 \\
15 \\
21 \\
18 \\
2\end{array}$ & $\begin{array}{r}16.60 \\
10.60 \\
17.60 \\
15.20 \\
20.80 \\
17.60 \\
1.60\end{array}$ \\
\hline
\end{tabular}

Table 1 presents the socio-economic profile of the respondents. It can be gleaned from the table that as to parents' occupation, most of the respondents' parents are into farming (60 percent); piggery/poultry (17.6 percent); teaching (5.80 percent), and construction work (2.40 percent). Furthermore, 1.20 percent of the respondents have parents who are into vending and 5.40 percent are government workers, i.e., administrative aid. Other identified occupations of the respondents' parents are housekeeping, tricycle driving and wood carving ( 7.60 percent).

As regards main source of family income, the respondents' families derive their income from vegetable farming 28.8 percent); rice and corn farming (23.40 percent); piggery/poultry ( 7.2 percent); carpentry with 7.80 percent; government employment (10.20 percent), and private employment (4.8 percent). Other sources of income like tailoring, tricycle driving, and wood carving etc. are 17.80 percent. It is important to note that other possible sources of income were not considered since it identified only the main sources of income of the respondents' family. 
In terms of family structure, majority of the respondents (78 percent) are raised by their mothers and fathers living together in the same household. Students also came from other family types such as single parent households with 22 percent.

As to religion, most of the respondents (68.40 percent) are Roman Catholics while 31.60 percent belong to other religious denominations such as Protestants, Iglesia Ni Kristo, Jehovah's Witnesses, Free Believers, Anglican and others. Lastly, with respect to the parents' highest educational attainment, a large number of respondents have mothers and fathers who are college undergraduate with 20.80 percent; 16.60 are elementary undergraduate; and 10.60 percent completed elementary. Moreover, 17.60 percent are high school undergraduate and college graduate; 15.20 percent are high school graduate and 1.60 percent obtained vocational studies.

It is noteworthy to state that in the study, the parents' highest educational attainment refers to whichever is the highest level of schooling obtained by either parent of the respondents.

\subsection{Academic Profile of Respondents}

The academic profile of the respondents is a valuable data to ascertain the scholastic background of the students. They provide a good scenario on their academic programs, year level and scholarships which are also essential as a backgrounder of their academic resiliency. This data is presented in Table 2 highlighting, among others, the courses, year level and the scholarship grants they received.

Table 2. Academic Profile of Respondents

\begin{tabular}{ccc}
\hline \hline Profile & $\begin{array}{c}\text { Frequency } \\
(\mathrm{N}=100)\end{array}$ & Percentage \\
\hline Course & 27 & 26.80 \\
Arts and Sciences & 7 & 7.40 \\
Health Sciences & 38 & 37.60 \\
Education & 7 & 6.60 \\
Applied Technology & 1 & .80 \\
Engineering & 12 & 12.20 \\
Criminology & 9 & 8.60 \\
Business Administration & Frequency & Percentage \\
& $(\mathrm{N}=100)$ & \\
Profile & & 36 \\
Year level & 36 & 48.60 \\
First year & 49 & 12 \\
Second year & 12 & 3.40 \\
Third year & 3 & 73.20 \\
Fourth year & 73 & 26.80 \\
No scholarship grants & 27 & \\
With scholarship grants & & \\
Scholarship Grants & & \\
No==========================================
\end{tabular}

As regards the courses enrolled by the respondents, majority of the respondents are into Teacher Education (37.60 percent); 26.80 percent are taking Arts and Sciences and 12.20 percent are into Criminology course. Additionally, 8.60 percent are enrolled in Business Administration; 7.40 percent are into Health Sciences; 6.60 percent have courses along Technology and .80 percent are taking Engineering courses. With respect to their year level, majority of the respondents are sophomores (48.60 percent), followed by freshmen (36 percent); juniors (12 percent) and seniors (3.40 percent).

With regard to the scholarships availed by the respondents, a great number of them ( 73.20 percent) did not avail of any scholarship program in the school. On the other hand, 26.80 percent are enjoying scholarship grants offered by government and private agencies. Government scholarships include among others, Local Government Unit, National Culture for Indigenous Peoples and One Town Scholars. In contrast, private scholarships include among others, Cordillera Green Network, Iluminada Dinulong Panabe Foundation, Congressional Scholars, etc.

\subsection{Socio-economic Condition of the Respondents}

The socio-economic condition is an important factor to consider in assessing the impact of poverty in the lives of the respondents. In this study, the socio-economic condition of the respondents is determined using the following 
parameters: shelter, household amenities, health facilities in the community, educational attainment of siblings, daily expenditure in school, daily allowances.

Table 3. Frequency and Percentage Distribution of Type of House and Ownership of the same by the Respondents

\begin{tabular}{lcc}
\hline \hline Shelter and ownership & $\begin{array}{c}\text { Frequency } \\
(\mathrm{N}=100)\end{array}$ & Percentage \\
\hline Type of House & 77 & 76.80 \\
Concrete & 13 & 13 \\
Semi-concrete & 10 & 10 \\
Temporary & 1 & .20 \\
Others & & \\
House and Lot & 90 & 89.80 \\
Owned & 10 & 9.80 \\
Mortgage & 1 & .40 \\
Rented & & \\
\hline \hline
\end{tabular}

As gleaned from Table 3, the type of shelter of the respondents is generally concrete (cemented hollow blocks) with 76.80 percent; temporary house with 13 percent usually made of wood, nipa, make shifts); 10 percent have houses which are semi-concrete or a combination of cement and wood or temporary materials. In terms of ownership of the house and lot, 89.80 percent of the respondents revealed that they own their present house and lot; 9.80 percent disclosed that their house and lot are under mortgage and .40 percent is renting their house and lot.

\subsection{Household Amenities or Facilities used by the Respondents}

To further show the socio-economic condition of the respondents, the study also investigated their household amenities which include their lighting, cooking, toilet and water source facilities. This is reflected in Table 4. In terms of lighting facility, a great number of the respondents ( 412 or 82.40 percent) have electricity; 60 or 12 percent still use candle and kerosene lamps; while few others (12 or 2.40 percent are using generators and solar which serve them for three to four hours a night. It is important to note that there are still areas in the Cordillera Region which have not yet reached or energized by the electric companies and this necessitates the far flung areas to use candles, kerosene and other sources of energy. 
Table 4. Frequency and Percentage Distribution of Household Amenities or Facilities used by the respondents

\begin{tabular}{lcc}
\hline \hline Household amenities & $\begin{array}{c}\text { Frequency } \\
(\mathrm{N}=100)\end{array}$ & Percentage \\
\hline Lighting facility & 12 & 12 \\
Candle /Kerosene & 3 & 3.20 \\
Gasul/Gasulette & 82 & 82.40 \\
Electric & 2 & 2.40 \\
Others (Generators, solar, petromax, etc.) & & \\
Cooking facility & 60 & 60.40 \\
Charcoal/Firewood & 1 & 1 \\
Kerosene & 37 & 37 \\
Gasul/Gasullette & 2 & 1.60 \\
Electric stove & 18 & 17.60 \\
Open pit privy & 22 & 21.60 \\
Pail type & 60 & 59.60 \\
Flush & 1 & 1.20 \\
Others & & \\
Toilet & 18 & 17.80 \\
Water source & 15 & 14.80 \\
Artesian well & 24 & 24.40 \\
Open well & 43 & 43 \\
Spring/Water falls/Creek & & \\
Public pipe & & \\
& &
\end{tabular}

Home appliances

Television Set

Refrigerator

Electric Fan

Electric Iron

Washing Machine

Rice Dispenser

Rice Thresher

Electric Stove

Transistor Radio

Home appliances

Chain Saw

Wall Clock

Sewing Machine

Betamax Player

Hand Tractor

Videoke/Karaoke

Water Dispenser

Gas Stove

Air Condition

Computer unit

VCD/DVD Player

Vehicle

(Tricycle, Jeep, Pick-up, Elf) 15

*multiple responses
With

$\mathrm{f}$
62
24
43
29
14
9
7
10
45

f

13

76

16

12

5

11

12

32

2

8

57

With

$\%$

62.40

24.40

42.80

29.40

14.20

9.42

7.20

10.42

44.60

$\%$

13.20

76

16

11.80

5.01

11.40

12

32

1.80

7.65

57.20

15.20
Without

$\begin{array}{lc}\mathrm{f} & \% \\ 38 & 37.60 \\ 77 & 77.40 \\ 57 & 57.20 \\ 71 & 70.60 \\ 86 & 85.80 \\ 9 & 9.40 \\ 93 & 92.80 \\ 90 & 89.58 \\ 55 & 55.40\end{array}$

Without

f $\%$

$87 \quad 86.80$

$24 \quad 24$

$84 \quad 84$

$88 \quad 88.2$

$95 \quad 94.99$

$89 \quad 88.60$

$88 \quad 88$

$68 \quad 68$

$98 \quad 98.2$

$92 \quad 92.35$

$\begin{array}{ll}43 & 42.8\end{array}$

$85 \quad 84.8$ 
As regards, cooking facilities, 302 or 60.40 percent are using charcoal/firewood; 185 or 37 percent use gasul/gasullette; 8 or 1.60 percent use electric stove; and 5 or 1 percent use kerosene. The widespread use of charcoal/firewood among the families of the respondents can be explained by the fact that trees abound in their localities. Moreover, the type of toilet facility used by the families of the respondents is the flush type (298 or 59.60 percent). The pail type comes next with 108 or 21.60 percent. Lastly, 88 or 17.60 percent and 6 or 1.20 percent respectively are users of the open pit privy and other toilet facilities.

\subsection{Daily Expenditure and Daily Allowance in School}

As a way of further showing the standard of living of the respondents, the study used the daily expenditure in school as an indicator. Such is presented in Table 5 showing that 36.6 percent of the respondents spend P10.00 to P20.00; 22 percent respondents spend P50.00 - P60.00 and 17.2 percent of them has P30.00 - P40.00 expenditure; 7.80 percent spend P90.00 - P100.00 and 7.60 spend above P100.00. Significantly, the daily expenditure of the respondents in school has a mean of P 44.25 .

Table 5. Frequency and Percentage Distribution of the Daily Expenditure and Daily Allowance in School

\begin{tabular}{|c|c|c|c|c|}
\hline \multicolumn{3}{|c|}{ Daily Expenditure and Daily Allowance in School } & \multirow[t]{2}{*}{$\begin{array}{r}\text { Frequency } \\
(\mathrm{N}=100) \\
\end{array}$} & Percentage \\
\hline \multicolumn{4}{|c|}{ Daily Expenditure in School } & \\
\hline P10.00 & - & P20.00 & 36 & 36.6 \\
\hline P30.00 & - & P40.00 & 21 & 20.60 \\
\hline P50.00 & - & P60.00 & 22 & 22 \\
\hline P70.00 & - & P80.00 & 5 & 5.20 \\
\hline P90.00 & - & P100.00 & 8 & 7.80 \\
\hline Above & - & P100.00 & 8 & 7.60 \\
\hline Mean & $=$ & 44.20 & Std. Dev. = & 35.361 \\
\hline \multicolumn{5}{|l|}{ Daily Allowances } \\
\hline P10.00 & - & P20.00 & 36 & 36 \\
\hline P30.00 & - & $\mathrm{P} 40.00$ & 17 & 16.8 \\
\hline P50.00 & - & P60.00 & 21 & 21 \\
\hline P70.00 & - & P80.00 & 5 & 4.8 \\
\hline P90.00 & - & P100.00 & 9 & 8.6 \\
\hline Above & - & P100.00 & 8 & 7.6 \\
\hline Mean & $=$ & 45.030 & Std. Dev. & 38.936 \\
\hline
\end{tabular}

With respect to the daily allowance of the respondents in school, it is revealed in the same table that the mean daily allowance is 45.07. Specifically, 36.4 percent respondents have an allowance of P10.00 - P20.00; 21 percent has a budget of P50.00 - P60.00 and 20.60 percent have P30.00 - P40.00. Others (8.6 percent) have allowance ranging from P90.00 - P100.00 and 8.6 percent have an allowance of P100.00 and above. On the whole, the indicators of socioeconomic conditions of the respondents reveal that most of the respondents come from poor families.

\section{Level of Academic Resilience of the Respondents}

A major investigation in this study is the determination of the academic resilience of the respondents. By definition, academic resilience means the students' ability to be academically successful despite the presence of numerous stresses in their lives. As gleaned in Table 6, the over-all weighted mean of academic resilience of the respondents is 3.64 which has a descriptive value of "much resilient". However, looking into the different items of the resiliency test, it can be deduced that the respondents are 'very much resilient' in accepting their poverty conditions. This is reflected in the weighted mean of $\mathbf{4 . 5 7}$ for the item, "Being a student coming from poor family, I take poverty as an inspiration and challenge".

There are plenty of items that show much resilient among the students. The top five of these items include (1) "I perform my obligation as a student in school well and good" with a weighted mean of 4.13. Interviews with the respondents reveal that the most common issue expressed was how to struggle with academic challenges and becoming a responsible student while performing their obligations. The second, "I can focus myself in my studies despite unfriendly classmates" got a weighted mean of 4.10. An interview with another student, Myra, has this comment: "When I notice unfriendly classmates I just act like I am alone in the classroom, I read my lessons alone and don't make myself too noticed in class and just don't get close to them if I know it won't end up well." Third, "I can manage my time even if it is very hectic and demanding" obtained a weighted mean of 4.06. The students mentioned that personal time management and organizational skills that they have developed help them greatly and lead them to go 
forward with their studies on time. Fourth, "My study is not affected by tribal wars" got a mean of 4.03. Similarly, Morales, 2008 found that students have vulnerability areas in class and race/ethnicity. Francis, a criminology student from Kalinga confirmed that "Tribal war is no longer a danger in our culture because there are already laws that limit this violence. This is why I can go to any school without fear of tribal war". Fifth, "I get motivated to study whenever I failed in quizzes" with a weighted mean of 4.01.

The data also show that the students are much resilient along the items such as "If I don't have allowance, I am more challenged to study hard" with a weighted mean of 3.99. "I am capable of doing my projects or requirements despite less access to computer and other technology" with a mean of 3.98. "I can work with someone who has different opinions than mine" has a mean of 3.93; A student fine his friends accommodating and caring even when he has done awful to them. He said "We all have our opinion. I am sure many of us have a different opinion than mine and I respect it." and "I enjoy learning topic/subjects with increasing difficulty" with a weighted mean of 3.91. Students perform best when the level of difficulty is slightly above their current ability level. If the task is too easy, it promotes boredom and may communicate a message of low expectations or a sense that the teacher believes the student is not capable of better work (Wang and Han, 1983). Moreover, the students are much resilient on the following items "The academic pressures I experience in the school become energy to do well in school" with a weighted mean of 3.89.

"I persevere more when my classmates are competitive" got a mean of 3.88. "I cope easily with differing opinions, views and perspectives inside the classroom" has a mean of (3.87). "I can manage to go to school even if there is one or two pairs of uniforms and limited school supplies" got the same mean of 3.87; The statements, "I don't problematize travelling from home to school and vice versa even if the distance is far" obtained a mean of 3.81. "The statements "I could bear the heat and other unfavorable conditions inside the classroom and the campus" and "My studies are not obstructed despite numerous family problems" both got a weighted mean of 3.80. "I can review my lessons even in a noisy boarding houses or residence." These students are able to take and with stand risks in their life which is a good manifestation of a resilient student and "I am "adaptive" by distancing myself from unhealthy people and situations" both got a weighted mean of 3.74." Taylor (1994) quoted that resilient students perceive themselves as being self-reliant, avoid problems or delinquent behavior and adequately manage their relations with peers and community.

I can handle the consequence of my decisions especially in my studies" got a weighted mean of 3.72. "If I have academic difficulties, I am capable of seeking assistance from classmates and teachers" with a weighted mean of 3.71 The following statements manifest much resiliency of the students. "I provide service through volunteering to help others for a cause in school" with a weighted mean of 3.61," The least statements under the "much resilient" are: My study is not affected by different cultural backgrounds of classmates and schoolmates" and "I can manage to study well even if I am away from my family member" with weighted mean of 3.60."

"I believe that I can learn even the most difficult lessons taught" with a mean of 3.58. "I can manage to shine and make good grades despite ridicule due to some personal related issues" with a mean 3.53. "I can adjust myself to changes in school to positively cope up with these changes" with a weighted mean of $\mathbf{3 . 4 8}$ Meanwhile, the students are moderately resilient to the following statements: "I don't give up easily even if the school requirements are many" with a weighted mean of 3.69. "I am not easily upset with too nagging teachers and bullying of friends" with a weighted mean of 3.66. "They rated themselves as moderately resilient to these factors: "I healthily cope with terror teachers and his difficult approach to teaching" have weighted of 3.47. "I can partake in extra Besides participating in extracurricular activities in school, I still manage to get high grades." "I am capable of balancing my studies with love life" with a weighted mean of $\mathbf{3 . 1 6}$ that mean moderately resilient. "I do part time jobs augment my allowance to school" with a mean of 3.12. " "I am not pressured with the increasing cost of fees and the cost of my education" with a weighted mean of 3.04. "I can study well even if the classroom environment is dirty and unconducive for learning" got a weighted mean of $\mathbf{2 . 7 3}$ "Less resilient" is marked among the students the item "I easily adjust to new policies, rules and regulations in the school" with a weighted mean of 2.53. It is inferred that students have a hard time to adjust to new policies, rules and regulations in the school. As an observation, whenever there is an adjustment or new policy the students complain to authorities or officials. School officials have difficulties to implement new policies to their students because students and parents resist every time. "It is because it takes time to adjust and get into a new policy. It takes a lot of effort to be flexible to policies."

\section{Level of Academic Performance of Respondents}

The level of the respondents' academic performance is presented in Table 7. In this study, the academic performance is measured in terms of the grade point average of the respondents in all their grades or enrolled subjects for $2^{\text {nd }}$ semester for Academic Year 2011-2012. 
Table 7. Level of Academic Performance of the Respondents

\begin{tabular}{|l|l|l|l|}
\hline Grade Point Average & Frequency & Percent & Qualitative Description \\
\hline $1.24-1.0$ & 1 & 1.20 & Excellent \\
\hline $1.5-1.25$ & 5 & 5.20 & Very Good \\
\hline $2.0-1.75$ & 41 & 41.40 & Good \\
\hline $2.5-2.25$ & 29 & 29.40 & Fair \\
\hline $3.00-2.75$ & 23 & 22.80 & Poor \\
\hline Mean $=\mathbf{2 . 0 2}$ & & & Good/Satisfactory \\
\hline
\end{tabular}

Legend:

Numerical description
$1.24-1.00$
$1.5-1.25$
$2.00-1.75$
$2.50-2.25$
$3.00-2.75$

Percentage description $97-100 \%$

93-96\%

$88-92 \%$

$83-87 \%$

$75-82 \%$
Qualitative description

Excellent

Very good

Good

Fair

Poor

It can be deduced from the table that the mean academic performance of the respondents is $\mathbf{2 . 0 2}$ with a descriptive value of good. This indicates that the respondents' academic performance is average or satisfactory. Perusing the Table 4 , however, it reveals that majority of the respondents (41.40 percent) have a grade point average of $2.0-1.75$ with a descriptive value of good; 29.40 percent got a grade point average of 2.5-2.25 which is fair; 22.80 percent obtained a grade point average of 2.75-3.00 (poor) while 5.20 percent garnered a grade of 1.25-1.50 (very good). Only 1.20 percent have obtained a grade of 1.0. This shows that overall academic performance of the respondents is good. This substantiates the interview of the students which disclosed that they are depressed due to low grades and their fear of failure in school. They emphasized that they are not satisfied with their academic performance. They reiterated that this was due to their adjustments to college life because they are only first years or second years who are fresh from high schools and that it is their first time to be away from their parents and relatives.

\section{Correlation between Academic Performance and Academic Resilience}

Table 8 presents the correlation of academic performance and academic resilience. As gleaned from the table, the result shows not significant on the relationship of performance and resilience as shown by its correlation matrix. There is no significant relationship between academic resilience and academic performance. Thus, the null hypothesis is accepted. This reveals that academic resilience does not influence academic performance.

Table 8. Correlation matrix between Academic Performance and Academic Resilience

\begin{tabular}{|l|l|l|l|}
\hline & ITEMS & $\begin{array}{l}\text { Academic } \\
\text { performance }\end{array}$ & $\begin{array}{l}\text { Descriptive } \\
\text { Values }\end{array}$ \\
\hline 1 & If I don't have allowance, I am more challenged to study hard. & .00377 & Not significant \\
\hline 2 & I get motivated to study whenever I failed in quizzes. & .02472 & Not significant \\
\hline 3 & $\begin{array}{l}\text { Being a student coming from poor family, I take poverty as an } \\
\text { inspiration and challenge. }\end{array}$ & .01632 & Not significant \\
\hline 4 & I do part time jobs augment my allowance to school. & .01674 & Not significant \\
\hline 5 & $\begin{array}{l}\text { The academic pressures I experience in the school become energy } \\
\text { to do well in school. }\end{array}$ & .02412 & Not significant \\
\hline 6 & I persevere more when my classmates are competitive. & .04879 & Not significant \\
\hline 7 & I anticipate academic problems and difficulties in the classroom. & .01459 & Not significant \\
\hline 8 & $\begin{array}{l}\text { I healthily cope with terror teachers and his difficult approach to } \\
\text { teaching. }\end{array}$ & .01598 & Not significant \\
\hline 9 & I easily adjust to new policies, rules and regulations in the school. & .04326 & Not significant \\
\hline 10 & $\begin{array}{l}\text { I can study well even if the classroom environment is dirty and not } \\
\text { conducive for learning. }\end{array}$ & .00576 & Not significant \\
\hline 11 & $\begin{array}{l}\text { I am not pressured with the increasing cost of fees and the cost of } \\
\text { my education. }\end{array}$ & .07956 & Not significant \\
\hline 12 & $\begin{array}{l}\text { I could bear the heat and other unfavorable conditions inside the } \\
\text { classroom and the campus. }\end{array}$ & .06962 & Not significant \\
\hline 13 & I don't give up easily even if the school requirements are many. & .10105 & Not significant \\
\hline 14 & I can manage my time even if it is very hectic and demanding. & .04435 & Not significant \\
\hline
\end{tabular}




\begin{tabular}{|c|c|c|c|}
\hline 15 & $\begin{array}{l}\text { I can manage to study well even if I am away from my family } \\
\text { member. }\end{array}$ & .020913 & Not significant \\
\hline 16 & I am capable of balancing my studies with love life. & .0298 & Not significant \\
\hline 17 & $\begin{array}{l}\text { I can partake in extracurricular activities without jeopardizing my } \\
\text { academic tasks or duties. }\end{array}$ & .10166 & Not significant \\
\hline 18 & $\begin{array}{l}\text { I am not easily upset with too nagging teachers and bullying of } \\
\text { friends. }\end{array}$ & .07366 & Not significant \\
\hline 19 & $\begin{array}{l}\text { If I have academic difficulties, I am capable of seeking assistance } \\
\text { from classmates and teachers. }\end{array}$ & .07056 & Not significant \\
\hline 20 & I enjoy learning topics/subjects with increasing difficulty. & .08806 & Not significant \\
\hline 21 & $\begin{array}{l}\text { I can handle the consequence of my decisions especially in my } \\
\text { studies. }\end{array}$ & .06144 & Not significant \\
\hline 22 & $\begin{array}{l}\text { I cope easily with differing opinions, views and perspectives } \\
\text { inside the classroom. }\end{array}$ & .06004 & Not significant \\
\hline 23 & I believe that I can learn even the most difficult lessons taught. & .09569 & Not significant \\
\hline 24 & My studies are not obstructed despite numerous family problems. & .09695 & Not significant \\
\hline 25 & I can focus myself in my studies despite unfriendly classmates. & .01569 & Not significant \\
\hline 26 & $\begin{array}{l}\text { I can manage to go to school even if there is one or two pairs of } \\
\text { uniforms and limited school supplies. }\end{array}$ & .00708 & Not significant \\
\hline 27 & My study is not affected by tribal wars. & .07142 & Not significant \\
\hline 28 & $\begin{array}{l}\text { I enroll regular units per semester and finish them with satisfying } \\
\text { grades. }\end{array}$ & .09511 & Not significant \\
\hline 29 & I find dropping and failing of subjects as an act of disgrace. & .00048 & Not significant \\
\hline 30 & $\begin{array}{l}\text { I can review my lessons even in a noisy boarding houses or } \\
\text { residence. }\end{array}$ & .09757 & Not significant \\
\hline 31 & $\begin{array}{l}\text { My studies is not affected by different cultural backgrounds of } \\
\text { classmates and schoolmates. }\end{array}$ & .07862 & Not significant \\
\hline 32 & I can handle peer pressure healthily. & .07508 & Not significant \\
\hline 33 & $\begin{array}{l}\text { I don't problematize travelling from home to school and vice } \\
\text { versa even if the distance is far. }\end{array}$ & .06146 & Not significant \\
\hline 34 & I perform my obligation as a student in school well and good. & .11352 & Not significant \\
\hline 35 & $\begin{array}{l}\text { I am capable of doing my projects or requirements despite less } \\
\text { access to computer and other technology. }\end{array}$ & .0427 & Not significant \\
\hline 36 & $\begin{array}{l}\text { I can manage to shine and make good grades despite ridicule due } \\
\text { to some personal related issues. }\end{array}$ & .091 & Not significant \\
\hline 37 & $\begin{array}{l}12345 \\
\text { others for a cause in school. }\end{array}$ & .0179 & Not significant \\
\hline 38 & $\begin{array}{l}\text { I can adjust myself to changes in school to positively cope up } \\
\text { with these changes. }\end{array}$ & .09082 & Not significant \\
\hline 39 & $\begin{array}{l}\text { I am "adaptive" by distancing myself from unhealthy people and } \\
\text { situations. }\end{array}$ & .09994 & Not significant \\
\hline 40 & I can work with someone who has different opinions than mine. & .13654 & Not significant \\
\hline & Total & .10328 & Not significant \\
\hline
\end{tabular}

\section{Summary of findings}

On the whole, the indicators of socio-economic conditions of the respondents reveal that most of them come from poor families and they live a simple life. This is generally seen in the following findings: (1) Majority of the respondents live in concrete house (cemented hollow blocks); (2) they use charcoal/firewood as cooking facility; (3) they have flush type toilet; (4) they derive their water from public pipe managed by the municipality or barangay which they pay at a minimal amount and; (5) most of the common items available in their houses are wall clock, television, VCD/DVD player, transistor radio, electric fan and gas stove/gasulette. For health service, the respondents largely depend on health services and facilities of the government in their places specifically the Barangay Health Station and most of their brothers and sisters are college undergraduate. Also, majority of the respondents spend P10.00 to P20.00 daily in school; they have a daily mean expenditure in school amounting to P 44.25 and they have a mean daily allowance of 45.07 . 
The study further reveals that the over-all weighted mean of academic resilience of the respondents is 3.64 which has a descriptive value of "much resilient". This implies that the respondents have "high" ability to be academically successful despite the stresses and challenges they experience in life. It also indicates that the respondents are optimistic, as they adopt a proactive and positive orientation to their studies. On the other hand, the level of academic performance of the respondents is $\mathbf{2 . 0 2}$ with a descriptive value of good. This indicates that the respondents' academic performance is satisfactory.

Finally, the study accepted the null hypothesis that there is no significant relationship between the respondents' academic resiliency and academic performance. This implies that academic resiliency does not in no way influence academic performance.

\section{Conclusions}

As manifested in the findings of this study, it can be concluded that poverty is very much felt by the students and the people in the study area as manifested by the inadequacy of their life's basic needs like shelter, household amenities and educational opportunities. Moreover, the students of Kalinga are academically resilient since they are able to successfully adjust and cope with stressful circumstances in their lives despite diversity. It is an indication that these respondents are optimistic, as they adopt a proactive and positive orientation to their studies. What make the respondents become resilient is their natural inclination to socialize and interact in a positive way with their classmates, teachers, schoolmates, dorm mates and other people whom they come in contact with. Their ability to socialize with them effectively became their instrument to hurdle their challenges and problems. Coupled with this is their great deal of self motivation and high hopes to succeed in all their endeavors. It was very vivid that these students really want to succeed in life despite the material and financial inadequacies they experience.

Thus, contrary to the general concept that the poor are passive, fatalistic, low aspiring, desperate, and think primarily of the present, the respondents are generally high aspiring, practical, hopeful, and futuristic in their outlook in life. Their definition of life is very pragmatic and existentialist as they trust their ability to craft and define themselves and their future. Accordingly, life is a choice, problems are surmountable and situations can be redefined according to their own expectations and aspirations. This fact reflects their idealism, vivacity and optimism as youngsters.

Rather than viewing poverty as an impediment, the respondents view it as a motivation in life. Poverty is a facilitating and a push factor that inspires them to achieve their aspirations. Being poor serves as a challenge, giving them great pressure and determination to succeed. They are more inspired whenever they think of the difficult work of the poor. They become stronger in facing problems because their daily experiences prepare them to surpass more challenging odds and crises now and later.

Optimistically, they expect education to be the "turning point" of their life and the key to getting out from generational poverty. It is the factor which shall give them "good life" or success. Good life is having a peaceful life, and obtaining all the needs one desires. While the respondents perceive studying as a means for a brighter future, they view it, however, as a form of survival. Facing numerous problems of school and family finances is a matter of "survival of the fittest" that tests of their endurance. It challenges their cognitive and emotional stamina, factors which are important for their continued existence in school. Interestingly, the schools where the respondents study foster resilience. This is achieved by the SUCs despite the fact that they have limited resources. This conveys that limited resources available in a school may not be a hindrance to achieving resiliency among its students. Thus, it can be said that the SUCs promote academic success of its students.

\section{Recommendations}

In view of the findings and conclusions of the study, the following recommendations are put forward:

1. More scholarship programs, other financial assistance and other programs that promote access to education must be provided by the schools to their students so that they will continue their studies and reach their dreams and aspirations. This is important since most of the respondents worry that they will not be able to finish their courses due to financial problem.

2. To maintain the resiliency of students in the study area, teachers or advisers should maintain and go beyond the academic arena and help students to better understand how their perceptions of self and their environment may affect their academic performance. This means that advising students should expand to include mentoring them.

3. The Directors of Office of Student Services and Welfare as well as the Guidance Counselors and all those involved in the crafting of student development activities and programs need to know the results of the study to strengthen further their services to the students. In this way, the poor students are able to healthily cope with the challenges and problems in their schooling especially when it comes hand in hand with their family problems. 
4. Considering that resiliency is important in the personal and academic development of the students, there is a need to incorporate resilience skill-building into the subjects and teaching strategies, students tend to experience academic resilience when they have opportunities to develop learning skills in problem solving and use of information; complete homework; and participate in class.

5. College and university orientation sessions should include presentations and classes on the variables that affect grade-point averages. Students who enroll in these sessions may develop a personal awareness of how these variables affect their performance.

6. The data show that students who interact and enjoy the company of others have higher grade-point averages than those who do not. Orientation activities should encourage students to socialize with those who are different from themselves and to help students begin developing the skill and comfort needed to interact effectively with other ethnic groups.

7. While the study can be one of the few studies that dwell on the academic resiliency among Filipino students, further research is needed however focused on its relationship with personality types, self esteem and other psychological attributes. Another recommendation for further research is the investigation of academic resilience on private tertiary schools as well as in the basic education. Finally, it is recommended that future research be devoted to a synthesis of studies of the variables associated with academic resilience of Filipino students at the undergraduate level which was not the focus of the present study.

\section{References}

Anderson, 1.w. \& Pellicer, 1. O. (1994). Compensatory education in South Carolina: Lessons from the past visions for the future. In K.K. Wong \& M.C. Wang (eds.), Rethinking policy for at-risk students (pp. 91-121). Berkeley, CA: McCutchan Publishing Corporation.

Appleton,s. \& Kingdon, g. Et.al., (2000). Does investing in education reduce poverty? Evidence from Ghana, Uganda and South Africa. CSAE, Economics Dept., Manor Rd. Oxford.

Astle, Barbara j. (2005). Higher education helps reduce poverty. UPCD. www.opportunity.org.au.

Battistich, V., Schaps, E., \& Wilson, N. (2004). Effects of an Elementary School Intervention on Students' "Connectedness" to School and Social Adjustment During Middle School. Journal of Primary Prevention, 24(3), 243-262

Benford, R. \& Newsome, J. (2006). Factors Affecting Student Academic Success in Gateway Courses at Northern Arizona University. Center for Science Teaching and Learning, Northern Arizona University.

Borman, Geoffrey.(2006). Beating the Odds Against Academic Success. Johns Hopkins University. UW-Madison

Boyd, Tiauna L. (2006). Educational Achievement and Resilience. Johns Hopkins University. UW-Madison

Bugnalen, Angelita P. (2005). Personal and Socio-Cultural Orientations in Relation to the Academic Achievement of Indigenous College Students in the Metropolis - Basis for a Responsive Guidance Program 2004-2005

Carlson, Devorah. Ph.D. (2001). Development and Validation of a College Resilience Questionnaire, The University of Nebraska - Lincoln, 2001, 146 pages; AAT 3016308

Catholic Educational Association Of The Philippines (CEAP) (2007) -Cordillera Administrative Region (CAR) Regional Assembly

Collins English Dictionary - Complete and Unabridged (C) HarperCollins Publishers 1991, 1994, 1998, 2000, 2003

Csikszentmihalyi, M. (1997). Finding flow: The psychology of engagement with developmental psychology: Perspectives on stress and coping (pp. 151-74).

Daguipil/NEDA-CAR, (2009). Poverty Incidence in CAR declines in 2009, Inquirer

De La Cruz, Allan O. (2009). Conceptions of Language Teachers in the Teaching of Grammar: An Assessment. Dissertation, Cagayan State University, Tuguegarao, Cagayan.

Driscoll, Anne K. (2000). Academic Resilience among Low SES High School Students.

University of California, Davis

Floyd, C. (1996), Achieving despite the Odds: A study of Resilience Among a Group of African-American high school seniors. The Journal of Negro Education, vol. 65,No. 2, 181-189.

Encyclopedia Britannica (2007 Edition)

Garmezy, N., \& Masten, A. S. (1991). The protective role of competence indicators in differences between resilient and non-resilient Latino middle school students. everyday life. New York: Harper Collins.

Gizir, Cem Ali; Aydin, Gul. (2009). Protective factors contributing to the academic resilience of students living in poverty in Turkey. Professional School Counseling

Goldstein \& R. Brooks (Eds), Handbook of Resilience in Children (107-121). Kluwer Academic/Plenum

Gonzalez, R., \& Padilla, A. M. (1997). The academic resilience of Mexican American

high school students. Hispanic Journal of Behavioral Sciences, 19, 301-17. 
Guererro, Carolina S. (2005) "The Other Side of Basic Education. Bureau of Alternative Learning Systems (BALS). IP Curriculum Validation Gathering, Richeville Hotel, Mandaluyong

Howell, K. W., \& Nolet, V. (2000). Curriculum-based evaluation: Teaching and decision- making. Belmont, CA: Wadsworth Thomson Learning.

Innabuyog, Alliance Of Indigenous Women's Organizations In The Cordillera ,Alliance Of Peasant In The Cordillera Homeland. (2008). Statement on the Occasion of World Rural Women's Day and World Foodless Day

Johnson, D.W. \& Johnson, R. (1987). Cooperation and Competition. Hillsdale, NJ: Lawrence Erlbaum Associates

Kassim O. Ajayi , K.O. Muraina. (2002) Parents' Education, Occupation and Real Mother's Age as Predictors of Students' Achievement in Mathematics in Some Selected Secondary Schools in Ogun State, Nigeria.

Kenny, M. E., Gallagher, L. A., Alvarez-Salvat, R., \& Silsby, J. (2002). Sources of support and psychological distress among academically successful inner-city youth. Adolescence, 37(145), 161-182.

Lee, V.E., Bryk, A.S., \& Smith, J.B. (1993). The organization of effective secondary schools. In L. Darling-Hammond (Ed.), Review of Research, Vol. 19, (pp. 171-267). Washington DC: American Educational Research Association

Lecroy, Craig Winston; Krysik, Judy. (2008). Predictors of Academic Achievement and School Attachment among Hispanic Adolescents.Children \& Schools

M. D. Glantz, \& J. Johnson (EDS.),( 2001) Resilience and development: Positive life adaptations (pp. 281-296). New York: Plenum.

M.Wang, M. Reynolds, \& H. Wahlberg (Eds.). (1999). Handbook of Special and Remedial Education: Research and Practice 2nd edition. (pp.159-200). New York: Pergamon.

Malanes, Maurice. (2008). How Cordillera children are deprived of education, Philippine Daily Inquirer

Margalit, M., \& Idan, O. (2004). Resilience and hope theory: An expanded paradigm for learning disabilities research. Thalamus, 22 (1), 58-64.

Masten, A. S. (1999). Resilience comes of age: Reflections on the past and outlook for the next generation of research. In M. D. Glantz, \& J. Johnson (Eds.), Resilience and development: Positive life adaptations (pp. 281-296). New York: Plenum.

Masten, A. S., \& Coatsworth, J. D. (1998). The development of competence in favorable and unfavorable environments: Lessons from successful children. American Psychologist, 53, 205-220.

Masten, A. S., Coatsworth, J. D., Neemann, J., Gest, S. D., Tellegen, A., \& Garmezy, N. (1995). The structure and coherence of competence from childhood through adolescence. Child Development, 66, 1635-1659.

Naglieri, J.A. \& Lebuffe, P. (2005). Measuring Resilience in Children. Kluwer Academic/Plenum.

Newman, F.M. \& Wehlage, G.G. (1991, October). Five standards of authentic instruction. Educational Leadership, 49(2), 8-12.

Okafor, Patrick C. (2007). A Case Study: Factors Contributing to the Academic Achievement of Low-Socio-Economic Status students in Anambra South County, Anambra State Nigeria. St. John's University.

Pacion, Joel M. 2010. The Hidden Curriculum of School Discipline: A Social Phenomenological Inquiry. A Dissertation. Cagayan State University. Tuguegarao City, Cagayan

Perez, William, Et.Al.(200). Academic Resilience Among Undocumented Latino Students. Claremont Graduate University.

Pianta, R., \& And Walsh, D. (1998). Applying the concept of resilience in schools: Cautions from a developmental systems perspective. School Psychology Review, 27, 407-417.

Robinson, J. (2000). Are there implications for prevention research from studies of resilience? Child Development, 71, $570-572$.

Shapiro, E. S. (2000). School psychology from an instructional perspective: Solving big, not little problems. School Psychology Review, 29(4), 560-572.

Shumow, Lee. Vandell, Deborah Lowe. Posner, Jill. (2002). Risk and Resilience in the Urban Neighborhood: Predictors of Academic Performance Among Low-Income Elementary School Children

Silva, John. (2007). Return to Sagada, Philippines, Sagada, Travel \& Commuting, Philippine Daily Inquirer

Sinay, Erhan. (2009). Academic Resilience: Students Beating the Odd. Organizational Development/Research \& Information Services, 416-394-4929 Vol. 5, Issue 1

Soriano, Ricardo C. (2008). Socio-economic Impact of Community-Based Forest Management Program on the Quality of Life of Forest-Dependent Beneficiaries in Cagayan Province. Dissertation. Cagayan State University. Tuguegarao, Cagayan

Tiangco, Joseph Anthony Z. (1999). Understanding the Filipino Philisophy of Resiliency: Katatagang-loob and Its Phenomenological Considerations. De La Salle University Press. 
Vera, E.M., \& Reese, L.E. (2000). Prevention interventions with school-age youth. In S.D. Brown \& R.W. Lent (Eds.), Handbook of Counseling Psychology (3rd ed., pp 411-434). New York: Wiley.

Victor, Lourie. (2008). The Faces and Challenges of Migration: The Cordillera Experience.

Wang, M. \& Haertel, G. (1995). "Educational Resilience.” In M.Wang, M. Reynolds, \& H.

Wahlberg (Eds.), Handbook of Special and Remedial Education: Research and Practice 2nd edition. (pp.159-200). New York: Pergamon.

Wang, M., Haertel, G., \& Walberg, H. (1994). "Educational resilience in inner cities." In Educational resilience in inner city America: Challenges and prospects. M. Wang, \& E. Gordon. (Eds.). 45-72.

Wang, Margaret C. And Walberg, Herbert D. (1997). Fostering Educational Resilience in Inner-City Schools. Publication Series No.4

Wasonga, Teresa; Christman, Dana E; Kilmer, Lloyd. (2003). Ethnicity, gender and age: Predicting resilience and academic achievement among urban high school students. American Secondary Education

Waxman, Hersh C. (2004). Educational resiliency: student, teacher, and perspectives. United States. Information Age Publishing Inc.

Werner, C. \& Kerig, P. (2000). Developmental Psychopathology: from infancy through adolescence. McGraw-Hill Companies, Inc.

Wolin \& Wolin (2003). Resiliency, Risk, and Substance Use Among Hispanic Urban Juvenile Detainees. Journal of Addictions \& Offender Couseling. George Washington University, Washington DC

Yates, T. M., \& Masten, A. S. (2004). Fostering the future: Resilience theory and the practice of positive psychology. In P. A. Linley \& S. Joseph (Eds.), Positive psychology in practice (pp. 521-539). Hoboken, NJ: Wiley.

Internet Sources

www.thoughts-about-god.com

Wikipedia, the free encyclopedia Psychological resilience

http://www.ched.gov.ph/hei_dir/index.html, accessed Dec. 4, 2008

http://edweb.tusd.k12.az.us/Kellond/special_programs

http://resiliency.com//htm/resiliencyquiz.htm

http://www.nscb.gov.ph/poverty/2009/default.asp

http://avin15.blogspot.com/

http://family.jrank.org/pages/1581/Single-Parent-Families.html\#ixzz1MBRTrBkydbetts@ boyertownasd.org

http://www.finestramedia.com/resiliency/ Siebert, Al. Interpretation - How Resilient Are You?

Henderson, Nan. M.S.W. 2002. The Resiliency Quiz, (02002. http://resiliency.com//htm/resiliencyquiz.htm

Kendra, Cherry. What Is Resilience? Coping With Crisis. Presentation®Superior Stimulus Delivery Free license for Eprime userswww.neurobs.com/ 